\title{
GOVERNAMENTALIDADE NEOLIBERAL E DESDEMOCRATIZAÇÃO: SOBRE O TRABALHO RECENTE DE WENDY BROWN
}

\author{
Guaracy Bolívar Araújo Mendes Júnior*
}

O trabalho da teórica política norte-americana Wendy Brown (1955 - ) visa lançar uma luz sobre os interditos e cláusulas ocultas nas práticas sociais e políticas da atualidade. O projeto geral da autora poderia ser descrito como a formulação progressiva de uma ontologia política do presente que em mais de um sentido avança questões levantadas por Michel Foucault sem, todavia, constituir-se em mero prolongamento ou epigonismo.

Se os trabalhos iniciais de Brown garantiram-lhe reconhecimento no campo dos estudos feministas, desde o início deste século percebe-se um progressivo aggiornamento do escopo de problemáticas abordadas pela autora. Certamente o acesso às posições defendidas por Foucault em $O$ nascimento da biopolítica (curso ministrado em 1979 no Collège de France) teve uma influência decisiva nessa fase de seu trabalho. Uma breve exposição do conteúdo do curso poderá iluminar esse passo decisivo.

"O nascimento da biopolítica" tem como foco a emergência das teorias neoliberais nas décadas iniciais do século XX. Retomando a bem conhecida crise das políticas sociais e econômicas liberais que acomete o início do século $\mathrm{XX}$ - e que teve como uma de suas consequências o avanço do keynesianismo e do Estado de Bem Estar Social nesse período Foucault mostra como economistas, filósofos, politicólogos e gestores públicos reconstituíram aspectos substanciais e centrais daquilo que ele denominará como governamentalidade liberal.

A noção de governamentalidade foi uma das mais significativas contribuições de Foucault ao léxico político contemporâneo. Por ela Foucault compreende formas de racionalidade política em atuação. Uma racionalidade política estabelece as condições epistêmicas, normativas e autorregulatórias que determinam as condutas de governantes e governados e suas relações. Na perspectiva de Foucault é preciso distinguir teorias e práticas políticas, mas também localizar e compreender suas articulações - e as consequências destas no plano de comportamentos induzidos por tecnologias e práticas sociais. A governamentalidade liberal clássica é caracterizada por Foucault enquanto baseada em uma gestão negativa das liberdades privadas que visa minimizar a esfera de atuação do Estado em

\footnotetext{
* Mestre em Filosofia pela Universidade Federal de Minas Gerais. Doutorando em Filosofia pela Universidade Federal do Rio de Janeiro. Professor Assistente III da PUC Minas. E-mail: guaracyaraujo@gmail.com.
} 
favor da iniciativa individual - e que ilude as comunidades ao assumir como legitimação uma sociedade civil que de fato é afastada dos processos de decisão.

A governamentalidade - ou racionalidade política - neoliberal emerge a partir do colóquio Walter Lippmann (Paris, 1938). Nesse evento estiveram presentes muitos dos personagens que posteriormente estariam no centro da disseminação do neoliberalismo pelo mundo - autores como Friedrich Hayek, Jacques Rueff, Wilhelm Röpke, Raymond Aron e Alexander von Rüstow. Nesse colóquio a questão central enfrentada pelos participantes consistia na substituição de teses caras ao liberalismo clássico por novas perspectivas ensejadas pelas transformações históricas envolvidas pelo nacionalismo, industrialismo e crises capitalistas. Uma das teses mais caras ao liberalismo econômico clássico foi aí submetida a uma dura prova: a suposição do caráter natural da regulação de mercado, conhecida pela expressão laissez faire. A posição que emerge do colóquio e que se tornará determinante na consolidação do neoliberalismo no EUA substitui a suposição de que o mercado deve ser deixado a seu próprio cargo pela afirmação da necessidade de reformular o Estado, as políticas públicas e sociais e mesmo a conduta dos indivíduos de acordo com as premissas de uma economia de mercado entendida como forma ótima de regulação e coordenação da vida social. Outra alteração fundamental é a mudança no status da intervenção do Estado diante da emergência de posicionamentos sociopolíticos. Resumindo a questão, os estados liberais clássicos herdaram da luta contra o absolutismo uma relativa capacidade de admitir matizes variados de posturas normativas e ideologias em seu seio, pois tais Estados vincularam sua legitimação social às liberdades individuais, ao menos em nível formal. Em comparação, o neoliberalismo afirmará a necessidade de uma ação permanente sobre todo o corpo social visando a sua própria legitimidade, que é como que produzida em ato - e assim podemos afirmar que a governamentalidade neoliberal será por princípio militantista e proselitista.

Em artigos e livros publicados nos últimos quinze anos, Wendy Brown assumiu esses elementos analíticos como ponto de partida para uma caracterização das formas de governo e exercício de poder político na contemporaneidade. Essa reflexão avançou em um crescendo; recuperemos brevemente esse percurso.

O primeiro desses textos é um artigo de 2003 intitulado Neoliberalism and the end of liberal democracy. Refletindo sobre os acontecimentos que vieram na esteira do 11 de setembro de 2001 (e em particular sobre o Ato de Segurança Patriótica promulgado à época por George W. Bush), Brown afirma que a erosão das liberdades públicas assinalada por esta 
e outras medidas de fato era apenas a ponta de um iceberg muito mais profundo. Cotejando as teses de Foucault acerca da governança neoliberal com as tendências recentes na vida social e política norte-americana e mundial, a autora afirma com clareza que a retração das liberdades individuais perceptível no governo de W. Bush é um sintoma do caráter pervasivo da racionalidade neoliberal que avança sobre os indivíduos, interações sociais, decisões políticas e elaborações teóricas.

Em American nightmare: neoliberalism, neoconservatism and de-democratization (2006), a autora retoma e avança essas posições. Nesse texto, que reflete sobre as similaridades nas posturas e discursos do neoliberalismo e do neoconservadorismo norteamericano, a autora fará um uso tópico do termo desdemocratização (“de-democratization"). Esse termo será o mote do ensaio "Hoje somos todos democratas", lançado no volume coletivo Démocratie, Dans Quel État? (2009) e que se apresenta aqui em sua primeira tradução para a língua portuguesa.

$\mathrm{O}$ argumento central desse ensaio - a afirmação da contrariedade intrínseca entre a racionalidade neoliberal e as premissas das democracias, incluindo aí as democracias liberais - será amplificado pela autora em seus livros seguintes: Walled States, Waning Sovereignity (2010) e, sobretudo, Undoing the Demos - Neoliberalism's Stealth Revolution (2015). Este último livro analisa a disseminação dos padrões mercadistas enquanto um verdadeiro solvente que, atuando em todas as dimensões da vida social (instituições políticas e jurídicas, ensino, meios de comunicação, etc.), formaliza e reduz sistematicamente as liberdades públicas e apresenta-se como uma das maiores ameaças históricas à efetivação de qualquer liberdade possível.

Os livros e artigos de Wendy Brown estão entre as mais vigorosas denúncias das consequências da implementação do projeto neoliberal. Todo aquele que na atual conjuntura sócio-histórica é vitimado por esse projeto terá muito a aprender com as considerações dessa pensadora. 